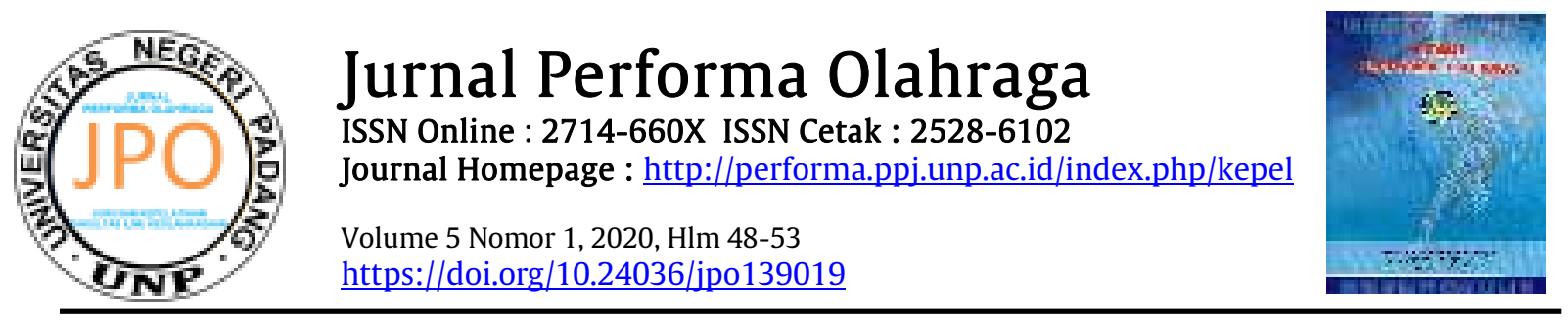

\title{
Pengaruh Metode Latihan Plyometrics terhadap Kecepatan Atlet Sepakbola SMA N 4 Sumbar FA
}

\author{
Restu Hidayat ${ }^{1}$, Witarsyah ${ }^{2}$ \\ FakultasIlmu Keolahragaan,Universitas Negeri Padang, Indonesia
}

\section{Informasi Artikel}

Diterima Jun 04-06-2020

Direvisi Aug 07-06-2020

Dipublikasikan 14-06-2020

\section{Keyword:}

Plyometric Exercise; Speed

\begin{abstract}
The problem in this study is the lack of speed of the SMAN 4 West Sumatra FA soccer athlete. The purpose of this study was to determine the effect of plyometric training on increasing the speed of soccer athletes at SMAN 4 West Sumatra FA. This type of research is quasy experiment (quasy experiment). This research was conducted in January to February 2020 in the West Sumatra PPLP field. The population in this study were all soccer athletes of SMAN 4 West Sumatra FA, amounting to 35 people. The sampling technique used purposive sampling, so the number of samples in this study were 15 athletes. The instrument in the study used a 30 meter run test. Data analysis techniques using statistical analysis techniques $t$ test. The results of this study are that plyometric training has no effect on increasing the speed of the soccer athlete of SMAN 4 West Sumatra FA with $(t h=-0.049<t t=1.76)$. Where from the average pre-test speed 4.51 seconds decreased to 4.54 seconds (decreased-0.03).
\end{abstract}

\section{Penulis Korespondensi:}

Restu Hidayat

Universitas Negeri Padang

hidayatrestu385@gmail.com

(c) 2020 The Authors. Published by Universitas Negeri Padang.

This is an open access article under the CC BY-NC-SA license

https://creativecommons.org/licenses/by-nc-sa/4.0

\section{PENDAHULUAN}

Olahraga prestasi membutuhkan kerjasama yang baik dari seluruh aspek yang ada dalam pelaksanaan pembinaan dan pengembangan olahraga prestasi, baik dari atlit itu sendiri melalui keinginan dan motivasi diri, dari pelatih dengan cara melatihnya yang baik dan sistematis, dan juga pemeritah dengan langkah pencarian atlit-atlit berbakat melalui pengadaan kompetisi yang berjenjang serta pengembangan yang berkesinambungan dan juga pengadaan sarana prasarana yang mendukung serta teknologi.Dari berbagai macam olahraga yang ada, olahraga Sepakbola merupakan olahraga yang paling terkenal di Dunia.Terlihat dari animo masyarakat yang menyaksikan setiap ada pertandingan Sepakbola. Terlebih, bila tim yang bertanding memiliki nama besar. Sejarah permainan Sepakbola masuk ke Indonesia dibawa dan diperkenalkan olah bangsa Belanda yang telah menjajah Indonesia.Pada masa penjajahan Belanda, persepakbolaan Indonesia diurus oleh Belanda sendiri. Satu-satunya bond yang ada pada waktu itu adalah NIVB (Nederlanshe Indonesische Voetbal Bond) yang berpusat di Jakarta atau Batavia. Alasan dari daya tarik Sepakbola terletak pada kealamian permainan tersebut, dalam permainan Sepakbola tidak membutuhkan peralatan yang banyak cukup ada bola dan lapangan yang datar. Tujuan utama permainan Sepakbola adalah mencetak gol sebanyak-banyaknya ke gawang lawan dan mempertahankan gawang dari kebobolan, sehingga tim yang berhasil mencetak gol terbanyak akan menjadi pemenang. Ketertarikan masyarakat terhadap Sepakbola kian pesat, bisa dibuktikan dengan banyaknya klub-klub Sepakbola dan akademi muncul di tengah-tengah masyarakat. 
Menurut Putra (2014) Sepakbola adalah permainan beregu di lapangan, menggunakan bola sepak dari dua kelompok yang berlawanan yang masing-masing terdiri atas sebelas pemain, berlangsung selama 2 x 45 menit, kemenangan ditentukan oleh selisih gol yang masuk ke gawang lawan. Secara umum hanya penjaga gawang saja yang berhak menyentuh bola dengan tangan atau lengan di dalam daerah gawangnya, sedangkan 10 (sepuluh) pemain lainnya hanya diijinkan menggunakan seluruh tubuhnya selain tangan, biasanya dengan kaki untukmenendang, dada untuk mengontrol, dan kepala untuk menyundul bola. Tim yang mencetak gol lebih banyak pada akhir pertandingan adalah

pemenangnya.Jika hingga waktu berakhir masih berakhir imbang, maka dapat dilakukan undian, perpanjangan waktu maupun adu penalty, tergantung dari format penyelenggaraan kejuaraan.Sepakbola adalah salah satu cabang olahraga permainan beregu yang dimainkan di lapangan terbuka dengan menendang bola yang bertujuan memasukkan bola ke gawang (Saputra, Dapid Rama, and Ronni Yenes, 2019).Menurut Ridl (2018) Sepakbola adalah suatu permainan yang dilakukan dengan cara menendang bola yang dilakukan oleh para pemain dengan sasaran gawang dan bertujuan memasukkan bola ke gawang lawan. Menurut Busyairi dan Ray (2019) Sepak bola merupakan permainan olahraga yang memprioritaskan kemampuan daya tahan aerobik yang baik atau VO2max yang tinggi. Untuk memenuhi tuntutan daya tahan tersebut seorang harus mempunyai energi dalam jumlah banyak. Tuntutan energi dalam jumlah banyak itu akan diproduksi melalu sistem aerobik yang memerlukan oksigen, oleh karena itu tinggi rendahnya daya tahan seorang para pemain tergantung dari tinggi rendahnya kapasitas oksigen maksimal atau VO2max.

Dedikasi klub maupun akademi Sepakbola yang ada mempunyai pengaruh yang besar terhadap perkembangan pencapaian prestasi Sepakbola di indonesia, sebab pembinaan yang terarah, sistematis serta berkesinambungan di terapkan terhadap pembentukan atlit-atlit yang berprestasi. Dalam permainan Sepakbola, setiap pemain harus mampu melakukan gerakan yang terampil di bawah kondisi permainan yang waktunya terbatas, fisik dan mental yang lelah dan sambil menghadap lawan. Harus mampu berlari beberapa mil dalam satu pertandingan dan menanggapi berbagai situasi permainan dengan cepat. Oleh sebab itu, setiap pemain Sepakbola harus di bekali dengan beberapa komponen utama dan saling terikat yaitu kondisi fisik, teknik, taktik dan mental.

Berdasarkan komponen olahraga prestasi tersebut, kondisi fisik merupakan komponen yang sangat penting.Begitu juga dalam sepakbola, setiap pemain harus menguasai unsur kondisi fisik. (Bompa, 1994 dalam Hidayat, 2014) menjelaskan bahwa Komponen dalam kondisi fisik ada 5 yaitu : Kekuatan, Daya tahan, Kecepatan, Kelentukan dan Koordinasi.

Menurut pendapat di atas maka ada beberapa komponen kondisi fisik setiap pemain harus kuasai untuk menjadi pemain sepakbola berprestasi.Kecepatan merupakan kondisi fisik yang sangat penting dalam permainan sepakbola.(Syarif Hidayat, 2014) mengemukakan bahwa

Kecepatan adalah kemampuan menempuh jarak tertentu dalam waktu sesingkat-singkatnya.

Sejalan dengan pendapat tersebut kecepatan dalam sepakbola sangat berpengaruh , hal ini dapat dilihat pada saat melewati lawan baik dengan bola maupun tanpa bola. Kecepatan digunakan ketika pemain menerima umpan atau bola daerah dari rekan dan mengadakan gangguan terhadap pemain lawan pada saat menggiring bola dalam kecepatan tinggi, melakukan serangan balik dan atau ketika saat transisi.Pemain yang memiliki kecepatan sangat bagus pada umumnya susah diantisipasi gerakannya oleh pemain lawan.

Menurut Sasmita, Ridwan Aji (2015) Peningkatan kecepatan lari dapat diperbesar dengan meningkatkan komponen- komponen pendukung kecepatan seperti, fleksibilitas, power otot, daya tahan anaerobik, koordinasi gerakan dan keterampilan tehnik lari. Dengan menggunakan metode zig-zag runada dua hasil besar yang akan didapatkan sekaligus, yakni melatih kecepatan serta kelincahan olahragawan. Menurut Aji Pradana (2013) Salah satu faktor penunjang kecepatan lari adalah faktor anatomis atau postur tubuh yang meliputi : ukuran tinggi, panjang, besar, lebar, dan berat tubuh. Keunggulan dalam postur tubuh memang memberikan

keuntungan tersendiri dalam olahraga.Supian, Ahmad, et al (2014) menyatakan bahwa Kecepatan dibutuhkan karena kecepatan adalah kemampuan untuk menempuh jarak tertentu terutama jarak pendek, dalam waktu yang sesingkat- singkatnya. Menurut Saputra, Novit (2013) Komponen kecepatan diperlukan oleh hampir semua cabang olahraga permainan yang 
dipertandingkan, termasuk di dalam permainan sepakbola. Pemanfaatan kecepatan dalam permainan sepakbola adalah pada saat bergerak berlari mengejar bola, mencari ruang, dan menggiringbola.

Dalam permainan sepakbolamodern ini, pada umumnya semua pemain dituntut untuk memiliki kecepatan. Kecepatan merupakan modal penting para pemain sepakbola professional, sebab bukan hanya untuk pemain yang beroperasi di lini sayap, bek sayap maupun di depan. Karena pelaksanaanya menuntut untuk menyerang dengan cepat kemudian dituntut untuk kembali bertahan dengan cepat ketika serangan balik oleh lawan.Oleh sebab itu kecepatan sangat dibutuhkan seluruh pemain baik ketika penyerangan maupun ketika bertahan.Berdasarkan penjelasan tersebut, maka dalam olahraga sepakbola perlu dilakukan latihan untuk meningkatan kecepatan.

Salah satu latihan yang peneliti terapkan sebagai latihan penunjang kecepatan atlet adalah latihan plyometrik, Menurut Kurniawan, Kurniawan, and Gilang Ramadan (2016) plyometric adalah

latihan yang dilakukan dengan sengaja untuk meningkatkan kemampuan atlet, yang merupakan perpaduan latihan kecepatan dan kekuatan. Perpaduan antara kecepatan dan kekuatan merupakan perwujudan dari daya ledak otot . Selanjutnya Adzkar, Rizwan Zakki, Saichudin Saichudin, and Eko Hariyanto (2016) Latihan plyometric melibatkan gerakan- gerakan yang digunakan untuk menguatkan jaringan otot dan melatih sel syaraf mela- kukan stimulus

berupa kontraksi otot dengan pola tertentu sehingga otot-otot dapat meng- hasilkan kontraksi yang sekuat mungkin da- lam waktu yang singkat. Latihan plyometric sangat membantu dalam mengembangkan keseluruhan sistem neuromuscular dalam rangka menu- njang pergerakan yang lebih besar, (Hidayat, Taufik, Saichudin Saichudin, and Rias Gesang Kinanti, 2018).

\section{METODOLOGI}

Penelitian ini termasuk penelitian eksperimen. Dapat disimpulkan bahwa penelitian eksperimen adalah penelitian yang menggunakan variabel yang dimanipulasi untuk melihat hubungan sebab-akibat. Penelitian ini bertujuan untuk mengetahui pengaruh dari latihan Plyometricterhadap Kecepatan Atlet Sepakbola SMA 4 Sumbar FA. Desain penelitian yang digunakan adalah One Group Pretest-Posttest Design. Pelaksaanan penelitian ini dilaksanakan dilapangan SMAN 4 SUMBAR FA padang karena merupakan tempat pemain melakukan latihan.Penelitian ini dilakukan mulai sejak 03 Januari s.d 06 Februari 2020. Populasi dalam penelitian ini adalah atlet Sepakbola SMAN 4 SUMBAR FA sebanyak 35 orang dengan rentang usia 16-18 tahun.Berdasarkan populasi diatas, pengambilan sampel yang di terapkan yaitu purposive Sampling.Disini peneliti mengambil sampel yang rutin mengikuti latihan berjumlah 15 orang. Sampel dalam penelitian ini ditetapkan dengan pertimbangan sebagai berikut: (1) Berada pada masa pengembangan latihan fisik, (2) Merupakan pemain prioritas, (3) Aktif mengikuti latihan, (4) Keterbatasan waktu. Instrumen dalam penelitian ini memakai instrument tes Sprint 30 Meter.Teknik analisis data menggunakan teknik analisis uji t.

\section{HASIL DAN PEMBAHASAN \\ HASIL}

Hasil Tes Awal (Pretest) Kecepatan Atlet Sepakbola SMA N 4 Sumbar FA

Berdasarkan analisis data tes awal pre test kecepatan Atlet Sepakbola SMA N 4 Sumbar FA, maka dari 15 orang sampel diperoleh skor maksimal $=3.95$ detik dan skor minimal $=5.01$ detik . Kemudian diperoleh standar deviasi $=0,27$ detik dan skor rata-rata $=4,51$ detik.Kecepatan Atlet Sepakbola SMA N 4 Sumbar FA, dari data pre test, tidak ada pemain yang memiliki skor kecepatan pada kelas interval 3.58-3.91. 5 (lima) orang (33,33\%) memiliki skor Kecepatan pada kelas interval 3.92-4.34, berada pada kategori baik. 8 (delapan) orang (53,33\%) memiliki skor kecepatan pada kelas interval 4.35-4.72, berada pada kategori sedang, dan 2 (dua) orang $(13,33 \%)$ memiliki skor kecepatan pada kelas interval 4.73-5.11, berada pada kategori kurang. Dari analisis data yang dilakukan diperoleh skor rata-rata 4,51 detik. Dapat disimpulkan data Kecepatan (pre test) Atlet Sepakbola SMA N 4 Sumbar FA, berada pada kategori sedang. 


\section{Hasil Tes Akhir (Post Test) Kecepatan Atlet Sepakbola SMA N 4 Sumbar FA}

Berdasarkan analisis data Tes Akhir Post Test kecepatan Atlet Sepakbola SMA N 4 Sumbar FA, maka dari 15 orang sampel diperoleh skor maksimal $=3,94$ detik dan skor minimal $=4,09$ detik. Kemudian diperoleh standar deviasi $=0,25$ detik dan skor rata-rata $=4,54$ detik. Kecepatan atlet Sepakbola SMA N 4 Sumbar FA, dari data Post Test, masih belum ada pemain yang memiliki skor kecepatan pada kelas interval 3.58-3.91. 2 (dua) orang (13.33\%) memiliki skor Kecepatan pada kelas interval 3.92-4.34, berada pada kategori baik. 10 (sepuluh) orang (66.67\%) memiliki skor kecepatan pada kelas interval 4.35-4.72, berada pada kategori sedang, dan 3 (tiga) orang (20\%) memiliki skor kecepatan pada kelas interval 4.73-5.11, berada pada kategori kurang.

Hasil Tes Akhir ( Post Test) Kecepatan Atlet Sepakbola SMA N 4 Sumbar FA

Dari analisis data yang dilakukan diperoleh skor rata-rata 4,54 detik. Dapat disimpulkan data Kecepatan (Post Test) Atlet Sepakbola SMA N 4 Sumbar FA, berada pada kategori sedang.

\section{PEMBAHASAN}

Pembahasan dalam latihan ini dilakukan berdasarkan dari kajian teori dan perhitungan statistik serta mengacu pada kesimpulan terhadap analisis yang telah dilakukan, maka selanjutnya akan dilakukan pembahasan. Dalam pembahasan ini, akan merujuk pada hipotesis yang diajukan dalam penelitian. Pengaruh latihan Plyometric terhadap Kecepatan Atlet Sepakbola SMAN 4 Sumbar FA.

Berdasarkan hasil penelitian menunjukkan bahwa tidak adanya pengaruh latihan plyometrik terhadap kecepatan atlet sepakbola SMAN 4 Sumbar FA dengan rata-rata pre test sebesar 4,51 detik dan post test nya menurun menjadi 4,54 (menurun0,03 detik). Kemudian hasil analisis uji beda mean (uji $t$ ) sebesar $t_{\text {hitung- }} 0.49$ sedangkan $t_{\text {tabels }}$ sebesar 1.76 dengan taraf signifikan $=0,05$ dan $n-1=14$. Berdasarkan pengambilan keputusan di atas maka $t_{\text {hitung }}>t_{\text {tabel }}(-$ $0.494<1,76)$.Maka Ha ditolak dan Ho diterima.Dapat dikatakan bahwa tidak terdapat pengaruh latihan plyometrik terhadap kecepatan atlet sepakbola SMAN 4 Sumbar FA.

Dari hasil penelitian yang dilakukan di lapangan, latihan menggunakan latihan plyometric untuk meningkatkan Kecepatan Atlet Sepakbola SMAN 4 Sumbar FA masih belum efektif dimana di dapatkan keseluruhan dari hasil penelitian, di lihat Kecepatan rata-rata pre-test Atlet Sepakbola SMAN 4 Sumbar FA dengan sebesar 4,51 detik dan post test nya menurun menjadi 4,54 (menurun0,03 detik).Rata-rata Kecepatan Atlet Sepakbola SMAN 4 Sumbar FA berada pada kategori sedang.

Melihat hasil temuan tersebut maka dapat disimpulkan bahwa tidak terdapat

pengaruh latihan plyometric yang signifikan terhadap kecepatan atlet Sepakbola SMAN 4 Sumbar FA.Hendri (2014:17) mengatakan bahwa Latihan adalah kegiatan atau aktifitas gerak fisik yang dilakukan secara berulang-ulang dengan tujuan untuk meningkatkan kemampuan fisik atau keterampilan gerak tertentu . Sedangkan menurut Radlclife dalam Bafirman dan Agus, (2010:84) Plyometric berarti latihan-latihan yang berkarakter dan kontraksi-kontraksi otot yang berkekuatan dalam respon terhadap kecepatan, muatan, dinamik dan jangkauan otot .

Untuk meraih prestasi terbaik, seorang perlu melalui suatu proses latihan yang panjang secara terprogram, sistematis, terarah dan berkesinambungan sesuai dengan olahraganya. Proses latihan merupakan rangkaian kegiatan fisik dan psikis (mental) yang dilakukan oleh atlet di bawah bimbingan pelatih untuk tujuan meningkatkan dan mempertahankan prestasi atlet. Jadi, pelatih harus mampu memilih metode latihan yang sesuai dengan tujuan yang akan dicapai.

Kecepatan merupakan salah satu komponen kondisi fisik yang sangat penting dalam Sepakbola.Seorang pemain sepakbola harus mempunyai kecepatan baik saat berlatih maupun saat bertanding.Banyak kegagalan yang dialami oleh pemain ketika dihadapkan dalam menerima umpang terobosan dari rekan setim. Pemain yang tidak mempunyai kecepatan akan mengalami kalah dalam berduel satu lawan satu dengan pemain belakang lawan, sebaliknya pemain yang memiliki kecepatan akan memenangkan duel dengan pemain belakang. Selain pemain depan, semua posisi pemain dalam permainan sepakbola sangat membutuhkan kecepatan dalam menyerang dan juga mempertahankan daerah permainan dari serangan lawan.

Berarti terhadap kecepatan atlet Sepakbola SMAN 4 Sumbar FA.Meskipun latihan plyometric berpotensi dalam meningkatkan kecepatan melalui peningkatan kekuatan otot, namun 
latihan ini juga memiliki kekurangan atau kelemahan.Kelemahan dari latihan plyometric ini adalah dari segi pelaksanaannya, karena latihan ini menitik beratkan pada kekuatan dan kecepatan dan mengkombinasikan kedua komponen kondisi fisik tersebut sehingga mudah menyebabkan kelelahan.

Tidak terlepas dari hasil yang diperoleh pada penelitian ini, faktor-faktor yang berkaitan dengan proses latihan juga sangat mempengaruhi hasil yang dicapai, seperti intensitas, durasi, volume, frekuensi dan interval dalam latihan itu sendiri. Karena masing-masing faktor tersebut turut berperan terhadap kelangsungan latihan yang terprogram.

Secara garis besar menurut (Syafruddin, 2013) dalam bukunya menjelaskan ada dua faktor yang mempengaruhi proses latihan sehingga hasil pengujian hipotesis ditolak, yaitu faktor internal dan faktor eksternal Faktor internal adalah faktor yang berasal dari dalam, yaitu dari diri atlet dengan segala potensinya, kemampuan fisik, teknik, taktik dan mental. Sedangkan faktor eksternal adalah faktor yang berasal diri luar diri meliputi pelatih, Pembina, iklim dan cuaca, gizi, sarana dan prasarana, organisasi, penonton, wasit, keluarga, dan sebagainya

Berdasarkan pendapat diatas dapat dilihat beberapa faktor yang mempengaruhi tidak adanya pengaruh latihan yakni , 1) masih kurang motivasi atlet Sepakbola SMAN 4 Sumbar FA untuk ikut berpatisipasi dalam pelaksanaan penelitian dapat dilihat dari kehadiran mahasiswa yang datang, dan 2) kurangnya keseriusan atlet Sepakbola SMAN 4 Sumbar FA dalam pelaksanaan penelitian sehingga latihan tidak berjalan maksimal. 3) Asupan gizi dan keseharian atlet yang tidak trkontrol oleh peneliti. Dengan demikian jelaslah bahwa latihan plyometric yang diberikan tidak dapat meningkatkan kecepatan.

\section{KESIMPULAN}

Berdasarkan hasil dilapangan serta analisis data yang telah dilakukan, maka diperoleh kesimpulan, latihan Plyometric tidak berpengaruh terhadap peningkatan kecepatan atlet Sepakbola SMAN 4 Sumbar FA dengan $\left(t_{h}=-0.494<t_{t}=1.76\right)$. Dimana dari rata-rata kecepatan pre test 4,51 detik menurun menjadi 4,54 detik (menurun 0,03 detik). Oleh sebab itu pelatih harus mampu memilih bentuk latihan yang sesuai dengan tujuan yang dicapai serta mempertimbangkan seluruh aspek pendukung dari latihan tersebut.

\section{DAFTAR PUSTAKA}

Adzkar, Rizwan Zakki, Saichudin Saichudin, and Eko Hariyanto."Pengaruh Latihan Plyometric (Barrier Hops) Terhadap Tinggi Lompatan Pemain Bola Basket Tim Putra Smkn 12 Malang."Jurnal Sport Science 4.3 (2016): 179-183.

Aji Pradana, Akhmad. "KONTRIBUSI TINGGI BADAN, BERAT BADAN, DAN PANJANG TUNGKAI TERHADAP KECEPATAN LARI CEPAT (SPRINT) 100 METER PUTRA (Studi pada Mahasiswa IKOR Angkatan 2010 Universitas Negeri Surabaya)."Jurnal Kesehatan Olahraga 1.1 (2013).

Bafirman, dan Agus, Apri.(2010). Pembinaan Kondisi Fisik. Padang: FIK UNP. Busyairi, Badruzzaman \& Ray Hamidie Ronald Daniel, 2018 PERBANDINGAN METODE INTERVAL TRAINING DAN CONTINUOUS RUN TERHADAP PENINGKATAN VO2MAX. Jurnal Terapan Ilmu Keolahragaan

Hidayat, Taufik, Saichudin, and Rias Gesang Kinanti. "Pengaruh Latihan Plyometric Depth Jump dan Jump To Box Terhadap Power Otot Tungkai pada Pemain Ekstrakurikuler Bolavoli SMK Teknologi Nasional Malang." Jurnal Sport Science 7.2 (2018).

Hidayat, S. (2014).Pelatihan Olahraga Teori dan Metodologi. Yogyakarta: Graha Ilmu.

Irawadi, H. (2017). Kondisi Fisik dan Pengukurannya. Padang: UNP Press. 
Kurniawan, Kurniawan, and Gilang Ramadan."Pengaruh Latihan Plyometric Terhadap Hasil Smash Pada Ekstrakurikuler Bolavoli."JUARA: Jurnal Olahraga 1.2 (2016): 110-120.

Putra, Anggoro Hastomo. 2014. MINI FOOTBALL SQUARE DI KOTA PONTIANAK. Jurnal online mahasiswa Arsitektur Universitas Tanjungpura

Ridl, Azi Faiz, 2018 PENGARUH METODE LATIHAN SMALL SIDED GAME TERHADAP KEMAMPUAN PASSING-STOPPING PERMAINAN SEPAKBOLA. Motion, Volume IX, No.2, September 2018

Saputra, Dapid Rama, and Ronni Yenes."Pengaruh Bentuk Latihan Small-Sided Games Terhadap Peningkatan Vo2 Max."Jurnal Patriot 2.3 (2019): 482-492.

Saputra, Novit. Pengaruh Kekuatan Otot Tungkai, Kecepatan Lari dan Ketepatan Tendangan terhadap Hasil Tendangan Kearah Gawang pada Klub Sepak Bola Persilang Divisi II Liga Jepara. Diss. Universitas Negeri Semarang, 2013.

Sasmita, Ridwan Aji. Pengaruh Latihan Zig-Zag Run Terhadap Kecepatan Lari Pemain Futsal.Diss. Universitas Muhammadiyah Surakarta, 2015.

Supian, Ahmad, et al. "Kontribusi Kecepatan Lari dan Kelincahan terhadap Kecepatan Dribbling Bola Basket pada Pemain Basket Putra SMKN 3 Banjarbaru."Jurnal Multilateral 13.1 (2014): 37-52.

Syafruddin.(2013). Ilmu Kepelatihan Olahraga. Padang: UNP PRESS 